\title{
Perlindungan Dan Keselamatan Kerja Dikapal: Suatu Tinjauan Normatif
}

\author{
Suhartoyo \\ Fakultas Hukum, Universitas Diponegoro \\ Suhartoyo@gmail.com
}

\begin{abstract}
This study aims to determine the protection and safety of work on board: a normative review. This research is normative legal research. The results showed that the implementation of legal protection for workers on ships or crew based on the form of protection, can be seen in terms of marine labor agreements, when viewed from the legal protection of labor in the sea in relation to the risk of hazards at sea it does not reflect definite legal certainty . Because, in the sea labor agreement only mentions in general not in detail.
\end{abstract}

Keywords: Work Safety, Ship Menpower, Legal Protection

\begin{abstract}
Abstrak
Penelitian ini bertujuan untuk mengetahui perlindungan dan keselamatan kerja di kapal: suatu tinjauan normatif. Penelitian ini merupakan penelitian hukum normatif. Hasil penelitian menunjukan bahwa pelaksanaan perlindungan hukum terhadap tenaga kerja di kapal atau anak buah kapal berdasarkan bentuk perlindungannya, dapat dilihat dari segi perjanjian kerja laut, jika dilihat dari perlindungan hukum tenaga kerja di laut kaitannya dengan resiko bahaya di laut maka tidak mencerminkan kepastian hukum yang pasti. Karena, dalam perjanjian kerja laut hanya menyebutkan secara umum tidak secara detail.
\end{abstract}

Kata Kunci: Keselamatan Kerja, Anak Buah Kapal, Perlindungan Hukum

\section{A. Pendahuluan}

Indonesia yang dikenal dengan Negara kepulauan yang mempunyai luas laut lebih besar bila dibandingkan dengan luas daratan, yaitu besarnya 2 (dua) kali luas daratan. Hal ini mengakibatkan pentingnya arti dari perhubungan laut sebagai sarana komunikasi antar pulau dalam mewujudkan persatuan dan kesatuan pertahanan keamanan, politik, sosial, budaya, dan khususnya di sektor ekonomi dan perdagangan. Namun sampai saat ini pengelolaan, pemberdayaan dan pemanfaatan perairan termasuk laut oleh Negara belum optimal untuk kesejahteraan rakyat. ${ }^{1}$ Keselamatan kerja di kapal harus selalu dijaga agar dapat berlayar dengan aman, lancar, cepat dan selamat sampai ke tempat tujuan.

\footnotetext{
${ }^{1}$ Djoko Triyanto,Bekerja Di Kapal,(Bandung:Mandar Maju 2005), halaman 1
} 
Di bidang transportasi laut, penerapan K3 juga sangat diperlukan karena keselamatan adalah indikator utama untuk mengukur keberhasilan transportasi di laut. Di era kemajuan teknologi dan komunikasi saat ini, kapal-kapal yang digunakan sebagai sarana pengangkut telah banyak disentuh oleh teknologi dan dilengkapi sarana navigasi yang memadai demi kepentingan kenyamanan dan keselamatan dalam perjalanan melalui laut. Walaupun demikian kecelakaan kapal laut masih sering terjadi sehingga semakin menambah dalam keprihatinan terhadap dunia transportasi laut. Lemahnya sistem keselamatan di laut menjadi penyebab potensial besarnya korban kecelakaan di laut.

Pada umumnya semua perlengkapan di kapal menggunakan peralatan atau mesinmesin yang berasal dari mesin-mesin uap dan peralatan atau instalasi listrik merupakan hal yang paling diutamakan. Sehingga sebelum melakukan pelayaran semua tersebut harus terkontrol dan dalam kondisi baik serta normal. Seorang tenaga kerja yang bekerja di kapal apabila mengalami kecelakaan yang berakibat cacat total atau cacat sementara tidak mampu bekerja atau bahkan mengakibatkan meninggal dunia, maka mereka atau para ahli warisnya akan mendapatkan ganti kerugian atau jaminan sosial sebagaimana diatur dalam SOR 1940 dan sepanjang tidak ada faktor kesengajaan. Demikian halnya, apabila kecelakaan kapal yang disebabkan kebakaran, tubrukan, atau bahaya-bahaya laut lainnya dan mengakibatkan banyak korban meninggal dunia, maka seorang nahkoda dan/atau penggantinya dapat diajukan ke Mahkamah Pelayaran untuk dimintai pertanggungjawaban selama melakukan pelayaran dan upaya-upaya yang telah dilakukanya dalam penyelamatan kapal beserta muatanya. ${ }^{2}$

Dasar hukum perlindungan pekerja di Indonesia antara lain :

a. Undang-Undang Nomor 13 Tahun 2003 Tentang Ketenagakerjaan

b. Undang-Undang Nomor 21 Tahun 2003 Tentang Pengesahan ILO Convention No. 81 Conserning Labour Inspection in industry and Commerse ( Pengawasan Ketenagakerjaan Dalam Industri dan Perdagangan )

c. Undang-Undang Nomor 21 Tahun 2000 Tentang Serikat Pekerja dan Serikat Buruh

d. Undang-Undang Nomor 24 Tahun 2011 Tentang Badan Penyelenggaraan Jaminan Sosial

\footnotetext{
${ }^{2}$ Ibid halaman 3
} 
e. Undang-Undang Nomor 7 Tahun 1981 Tentang Wajib Lapor Ketenagakerjaan

f. Undang-Undang Nomor 1 Tahun 1970 Tentang Keselamatan Kerja

g. Undang-Undang Nomor 3 Tahun 1969 Tentang Persetujuan Konvensi ILO No. 120 Mengenai Hygiene dalam perniagaan dan kantor-kantor

h. 8 konvensi dasar ILO ( penghargaan terhadap hak asasi manusia di tempat kerja ), dibagi 4 kelompok :

- Kebebasan berserikat ( Konvensi ILO No. 87 dan No. 98 )

- Diskriminasi ( Konvensi ILO No. 100 dan 1010 )

- Kerja Paksa ( Konvensi ILO No. 29 dan No. 105 )

- Perlindungan Anak ( Konvensi ILO No. 138 dan 182 )

i. Peraturan Pemerintah Nomor 78 Tahun 2015 Tentang Pengupahan

j. Peraturan Presiden Republik Indonesia Nomor 21 Tahun 2010 Tentang Pengawasan Ketengakerjaan.

Pemerintah telah membuat peraturan-peraturan yang dimaksudkan untuk memberikan perlindungan terhadap pekerja/buruh, dalam kenyataanya masih saja terjadi pelanggaran. Bahkan tidak jarang kenakalan pengusaha sampai berani mengelabui pihak-pihak yang akan melakukan pengawasan di tempat kerja. Apabila hal ini sampai terjadi tidak menutup kemungkinan kecelakaan kerja akan terjadi, maka pengusahalah yang seharusnya bertanggung jawab atas seluruh kejadian dalam kecelakaan kerja

PT.Pelayaran Nasional Indonesia merupakan perusahaan milik negara (BUMN) yang memiliki beberapa divisi pekerjaan yang masing-masing pekerjaan tersebut juga memiliki tingkat bahaya kecelakaan kerja yang cukup tinggi. Dengan demikian, maka jelas sistem jaminan keselamatan yang diberikan kepada seluruh karyawannya terkait dengan sistem jaminan keselamatan dan kesehatan kerja itu menjadi hal yang sangat penting untuk diberlakukan. Agar pelaut-pelaut di Indonesia merasa mendapatkan perlindungan hukum yang wajar, dengan adanya keseimbangan antara hak dan kewajiban serta adanya standar kesejahteraan, yang tidak jauh berbeda dengan pelautpelaut asing, sehingga pelaut tidak berpindah ke perusahaan kapal asing yang telah menjamin kesejahteraannya, hendaknya pengusaha kapal di Indonesia khususnya PT.Pelayaran Nasional Indonesia (Pelni) mengantisipasi dengan memberikan jaminan perlindungan hukum yang memadai, karena kalau sampai banyak pelaut yang bekerja 
di perusahaan kapal asing akan merugikan perusahaan pelayaran dalam negeri khususnya dan negara pada umumnya, yang dampaknya mempengaruhi kehidupan ekonomi, sosial, politik dan budaya, mengingat tenaga pelaut adalah tenaga profesional yang mahal dan langka.

Usaha pokok PT.Pelayaran Nasional Indonesia (Pelni) adalah menyediakan jasa angkutan transportasi laut yang meliputi jasa angkutan penumpang dan jasa angkutan muatan barang antar Pulau. Berdasarkan usaha pokok tersebut, bidang usaha yang dijalankan oleh PT.Pelayaran Nasional Indonesia (Pelni) antara lain:

1. Jasa pengangkutan penumpang dan barang dengan jaringan pelayaran berjadwal maupun pelayaran yang melayani permintaan tertentu.

2. Jasa keagenan.

3. Jasa operasi terminal, pergudangan, angkutan rede dan ekspedisi/forwarding.

4. Jasa pemeliharaan kapal dan usaha dok atau reparasi kapal.

5. Charter dan broker kapal.

6. Jasa konsultan, pendidikan, pelatihan dan pelayanan kesehatan

Alat transportasi laut merupakan jawaban yang tepat dalam menunjang

kelancaran arus pengangkutan barang. Oleh karena itu perwira pelayaran niaga dituntut yang disiplin, terampil dan gesit dalam melaksanakan tugasnya. Dalam pengoperasian kapal ditemukan banyak pekerjaan-pekerjaan baik yang ringan maupun berat yang memiliki tingkat resiko kecelakaan kerja yang cukup tinggi. Dalam penelitian ini penulis mengamati sering terjadinya kecelakaan kerja pada awak kapal. Seringnya terjadi insiden atau kecelakaan pada awak kapal sewaktu bekerja baik di deck maupun di kamar mesin disebabkan karena kurang memperhatikan dan mengutamakan keselamatan. Sehubungan dengan itu maka awak kapal mempunyai tugas dan tanggung jawab yang besar dalam mencegah kecelakaan yang dapat menyebabkan kerugian dan penderitaan bagi semua pihak mulai dari awak kapal itu sendiri sampai pada tingkat perusahaan yaitu melalui usaha keselamatan kerja yang baik.

Perusahaan pelayaran dalam hal ini PT.Pelayaran Nasional Indonesia (Pelni) Semarang lebih berhati-hati dalam memilih orang atau karyawan yang akan ditempatkan pada bagian kapal, hal ini salah satu cara untuk menghindari terjadinya kecelakaan di laut. Karyawan yang handal, berkualitas dan mempunyai keterampilan 
yang sesuai dengan standarnya. Pelaksanaan menejemen keselamatan dan kesehatan kerja merupakan bagian dari perlindungan bagi karyawan. Hal tersebut sesuai dengan Pasal 151 Undang-Undang Nomor 17 Tahun 2008 tentang Pelayaran, dimana awak kapal harus mendapatkan perlindungan selama dalam masa kontrak kerja. Jika pemberi kerja tidak memberikan perlindungan kepada awak kapalnya, maka terdapat sanksi administrative. Banyaknya permasalahan yang timbul akibat tidak adanya perlindungan dapat mengakibatkan kerugian baik bagi pemberi kerja maupun pekerja (awak kapal).

\section{B. Pembahasan}

\section{Keselamatan Kerja di Kapal}

Keselamatan kerja di laut tidak saja bergantung dari kapalnya, awak maupun peralatannya, tetapi terutama kesiapan dari peralatan-peralatan tersebut untuk dapat digunakan setiap saat, baik sebelum berangkat maupun di dalam perjalanan. ${ }^{3}$ Di dalam pengangkutan di laut kapal itu merupakan alat utama untuk melakukan pelayaran menyeberang laut. Kapal yang digunakan sebagai alat angkutan itu senantiasa dalam keadaan mampu untuk berlayar. Setiap kapal itu akan melakukan pelayaran menyeberang laut, maka kapal itu harus telah siap "layak laut". 4 Kesiapan peralatan penolong diatur di dalam peraturan No.4 SOLAS'74 yang berbunyi :

a. Asas umum yang mengatur ketentuan tentang sekoci-sekoci penolong dan alat-alat apung di kapal yang termasuk dalam bab ini ialah bahwa kesemuanya harus dalam keadaan siap untuk digunakan dalam keadaan darurat.

b. Untuk dapat dikatakan siap, sekoci penolong, rakit penolong dan alat apung lainya harus memenuhi persyaratan sebagai berikut :

- Harus dapat di turunkan ke air dengan selamat dan cepat dalam keadaan trim yang tidak menguntungkan dan kemiringan.

- Embarkasi ke dalam sekoci maupun rakit penolong harus berjalan lancar dan tertib.

\footnotetext{
${ }^{3}$ Politeknik Ilmu Pelayaran, Basic Safety Training, halaman 2

${ }^{4}$ Wiwoho Soedjono, Hukum Laut, khusus tentang pengangkutan barang di Indonesia (Yogyakarta:Liberty Yogjakarta, 1986,) halaman 12
} 
- Tata susunan dari masing-masing sekoci, rakit penolong dan perlengkapan-perlengkapan dari alat apung lainya, harus sedemikian rupa sehingga tidak mengganggu operasi dari alat-alat tersebut.

c. Semua alat penolong harus dijaga supaya berada dalam keadaan baik dan siap digunakan sebelum meninggalkan pelabuhan dan setiap saat selama pelayaran. Sesuai dengan ketentuan Konvensi Internasional mengenai Keselamatan Jiwa Manusia di Laut 1974 (SOLAS”74), alat-alat penyelamat terdiri dari :

a. Sekoci penolong

b. Rakit penolong

c. Pelampung penolong

d. Rompi renang

e. Alat-alat pelempar tali

f. Alat-alat apung lainya

Hak dan kewajiban majikan maupun buruh $:^{5}$

1. Hak dan kewajiban majikan (pengusaha pelayaran)

Kewajiban majikan sebagai akibat adanya perjanjian kerja adalah untuk membayar upah kepada para buruhnya, menetapkan pengaturan pekerjaan baik bagi nahkoda maupun anak buah kapal, menunjuk sebuah kapal tertentu di mana melaksanakan serta memberi instruksi-instruksi kepada para buruhnya dalam rangka penyelenggaraan pelaksanaan pelayaran/pengangkutan di laut. Sedangkan hak pengusaha pelayaran sebagai majikan sebagai akibat adanya perjanjian kerja laut adalah untuk menuntut para buruh, baik itu nahkoda maupun anak buah kapal agar mereka melaksanakan pekerjaan dengan baik sesuai dengan perjanjian yang telah dibuat.

2. Hak dan kewajiban buruh

Sebagai akibat adanya perjanjian kerja laut, maka menimbulkan kewajiban bagi para buruhnya untuk melakukan pekerjaan pekerjaan pada pengusaha pelayaran sesuai dengan macam pekerjaan yang telah disetujui. Sedangkan yang menjadi hak buruh sebagai akibat perjanjian kerja laut itu adalah hak atas upaya yang ditentukan sesuai dengan macamnya pekerjaan yang dilakukan.

\footnotetext{
${ }^{5}$ Wiwoho soedjono, Hukum Perjanjian Kerja Laut,(Jakarta: PT Bina Aksara, 1987), halaman 26
} 
Guna mewujudkan suatu lingkungan kerja yang aman dan memadai di kapal, dan berdasarkan peraturan, kecakapan dan keterampilan pelaut, maka semua pihak yang bekerja di kapal dibebankan tugas dan tanggung jawab.

1. Tugas dan tanggung jawab seorang nahkoda dalam keselamatan kerja secara umum harus menjaga dan memperhatikan antara lain $:^{6}$

a. Agar lingkungan kerja untuk awak kapal tidak berada dalam hawa panas dan lembab

b. Apabila pada suatu saat awak kapal bekerja di tempat yang tidak tersedia hawa segar, agar sewaktu-waktu awak kapal diberi kesempatan untuk menghirup udara

c. Jemuran agar tidak terdapat di dalam ruangan mesin

d. Tangga-tangga lambung kapal harus berada dalam keadaan baik, dipasang pagar pada setiap sisi, tidak boleh kurang dari ukuran-ukuran yang ditentukan serta peraturan yang mengaturnya

e. Perlindungan terhadap bahaya kebakaran. Seperti tanda "Dilarang Merokok" harus dipasang dan terlihat jelas di berbagai tempat yang rawan terhadap bahaya kebakaran, supaya tempat penyimpanan bahan-bahan yang menimbulkan bahaya diperhatikan dan jangan dicampurkan. Demikian juga peralatan listrik pribadi di dalam ruangan supaya dihindarkan, pekerjaan mengelas dan memotong dalam perbaikan suatu kerusakan supaya benar-benar memperhatikan ruangan sekitar.

f. Pemakaian cat-cat

Mengingat cat mengandung berbagai bahan yang berbahaya, maka pemakaianya harus mengikuti tata cara yang aman sesuai dengan aturan yang berlaku.

g. Semua hal harus diperhatikan ketika akan mengolah atau mengoperasikan gerak kapal, untuk merapat atau melepaskan ikatan.

h. Hal-hal yang berkaitan dengan pekerjaan di geladak dan ruangan-ruangan muat, seperti : benda di geladak yang dapat mengganggu supaya dicat untuk menarik perhatian, lampu-lampu penerang di ruang muat harus

\footnotetext{
${ }^{6}$ Djoko triyanto, Op.Cit, halaman 87
} 
berfungsi dengan baik, sedang pengapian terbuka dilarang, lampu jinjing harus terlindungi dengan baik, pagar-pagar sekitar palkah benar-benar terjamin kedudukanya.

i. Tutup dan buka palkah

Tutup dan palkah atau selama palkah terbuka, harus diberikan penerangan secukupnya, penutup palkah dari kayu harus terlindung dengan pintu baja, boyo-boyo harus diberikan rantai pengaman waktu diangkat atau diturunkan kembali ketempatnya serta diberikan nomor urut untuk memudahkan penempatan. Tutup palkah hendaknya jangan digunakan untuk tujuan-tujuan lain, sedangkan tutup palkah yang mekanis harus disertai dengan instruksi dari pabrik pembuatanya bagaimana melayani dan mengoperasikan serta di tempatkan di tempat yang mudah terlihat dekat tempat kerja.

j. Tangki dalam (Deep Tank)

Tangki-tangki dalam yang sedang terbuka diberi pagar pelindung, dan awak kapal yang bekerja di dalam tangki tersebut untuk membersihkan dengan bahan kimia harus dilindungi dengan tali pengaman, pakaian pelindung maupun alat pernapasan bila diperlukan.

k. Muat bongkar

Penyusunan muat di dalam palkah harus mengikuti ketentuan penyusunan muatan, sedangkan di palkah harus diberi supaya ada tanda garis terhadap lubang palkah dengan suatu jarak tertentu dengan sekelilingnya

1. Muatan geladak

Sebaiknya muatan geladak tidak di tempatkan dekat kepala palkah, karena untuk memudahkan pekerjaan terhadap palkah.

2. Keselamatan Mesin-mesin/Pesawat Uap

Penggunaan mesin dan pesawat uap di kapal harus memenuhi ketentuan yang terdapat dalam Undang-Undang Uap 1930 (Stoom Ordonantie 1930) yaitu Stb.1930 Nomor 225 dan Peraturan Uap 1930 (Stoom verordering 1930) Stb. No. 339. Yang dimaksud dengan pesawat uap dalam Undang-Undang Uap 1930 Stb. 1930 Nomor 225 adalah suatu ketel uap dan setiap pesawat yang diterapkan dengan peraturan pemerintah secara langsung atau tidak 
langsung dihubungkan dengan suatu ketel uap dan diperuntukkan guna bekerja di bawah tekanan yang lebih tinggi dari tekanan udara biasa. Sedangkan ketel uap adalah suatu pesawat yang dibangun untuk menghasilkan uap yang dipergunakan di luar pesawat tersebut. ${ }^{7}$

Pasal 2 Undang-Undang Uap 1930 Stb. 1930 Nomor 225, yang dimaksud peralatan dari suatu pesawat uap adalah semua alat-alat yang menggunakan uap dengan aman dari pesawat uapnya.

3. Keselamatan Peralatan Instalasi Listrik

Dalam keadaan bagaimanapun, pesawat-pesawat atau mesin-mesin listrik hanya diperbolehkan diberi aliran listrik dari perusahaan yang bersangkutan (perusahaan pelayaran atau pekerjanya yang menguasai bidang kelistrikan kapal).

1. Pemasangan peralatan listrik ${ }^{8}$

a. Pemasangan transformator-transformator, panel-panel, sakelar-sakelar, motor-motor dan alat-alat listrik lainnya di tempat kerja harus dilaksanakan sedemikian rupa sehingga tidak terdapat bahaya kontak dengan bagian-bagian yang bertegangan.

b. Manakala ruangan dan persyaratan pelayanan memungkinkan, alat-alat dan pesawat-pesawat listrik harus di tempatkan dalam ruangan terpisah yang ukuranya memadai dan hanya orang-orang yang berkompeten boleh masuk ke dalam ruangan tersebut.

c. Jika alat-alat atau pesawat listrik terpaksa di tempatkan di tempat kerja dalam ruangan produksi, pagar pengaman untuk melindungi bagianbagian atau penghantar yang bertegangan harus dibuat.

d. Perlu di pasang papan tanda larangan masuk bagi mereka yang tidak berkepentingan dan disertai peringatan "Awas Bahaya Listrik"

e. Terdapat kesesuaian dalam banyak hal mengenai norma-norma bagi pagar pengaman untuk mesin dan pesawat listrik

f. Petugas-petugas perawatan listrik harus tahu benar bahaya-bahaya yang bertalian dengan suatu instalasi listrik dan peralatan lain-lainya

${ }^{7}$ Ibid, halaman 96

${ }^{8}$ Ibid, halaman 137 
g. Bahaya-bahaya akibat listrik harus dipertimbangkan pada perencanaan pembuatan tutup pengaman bagi panel listrik

h. Pemasangan peralatan listrik harus memenuhi persyaratan yang ditetapkan dalam Peraturan Umum Instalasi Listrik (PUIL) dan peraturan-peraturan lain tentang keselamatan kerja listrik

i. Macam pemasangan instalasi listrik di perusahaan-perusahaan dan tempat-tempat kerja tergantung dari konstruksi bangunan ukuran dan pembagian beban, penempatan mesin-mesin, pesawat dan alat-alat listrik, keadaan ruang kerja seperti : berdebu, panas, lembab dan lain sebagainya

j. Isolasi dan hantaran listrik harus disesuaikan dengan keperluanya

k. Pemeriksaan berkala terhadap tahanan isolasi, kawat hantaran, alat-alat dan pesawat listrik harus dilakukan oleh pejabat yang berwenang

1. Laporan hasil pemerikasaan perlu untuk pelaksanaan program keselamatan kerja listrik

m. Penempatan dan pemasangan motor-motor listrik tidak boleh mengganggu lalu lintas pekerja

n. Motor-motor yang tidak tertutup tidak boleh di tempatkan di ruangan lembab, menggigit, berdebu atau ruangan yang mudah terbakar

o. Petugas perawatan listrik harus terlebih dahulu mengetahui bahayabahaya yang mungkin timbul dan melakukan pencegahan sebaikbaiknya

2. Sakelar

a. Apapun tipe sakelar, yaitu tombol tekanan, tuas, putar atau otomatis, harus memenuhi syarat keselamatan

b. Sakelar-sakelar untuk keperluan motor-motor, pesawat-pesawat listrik, instalasi cahaya dan tenaga harus ditutup

c. Sakelar tuas :

1. Tidak boleh dipakai sakelar tuas yang terbuka, oleh karena bagianbagian terbuka yang bertegangan akan menimbulkan bahaya 
tekanan arus listrik dan dapat mengakibatkan loncatan api, bila sakelar diputuskan arusnya

2. Sakelar tuas harus tertutup dan tutup serta poros pegangan (handel) harus dihubungkan ke tanah

3. Sakelar-sakelar tuas harus dipasang sedemikian sehingga bagianbagiannya yang dapat digerakkan dalam keadaan tidak ada hubungan tidak bertegangan

d. Sakelar pemisah :

1. Bila dipakai sakelar pemisah untuk tegangan tinggi, sakelar harus dipasang di luar batas capai tangan dan pelayananya dilakukan dengan menggunakan tongkat pengaman

2. Bila pemasangan seperti tersebut pada angka (1) tidak dimungkinkan, sakelar tersebut harus ditutup atau dipagar secara tepat agar tidak membahayakan, sedangkan pelayanannya tetap dilakukan dengan memakai tongkat pengaman

e. Untuk keperluan pemakaian secara umum, dianjurkan agar dipakai sakelar putar atau tombol tekan, oleh karena bagian yang bertegangan berada di tempat tertutup

f. Sakelar-sakelar yang dapat menimbulkan loncatan api harus dipasang dalam peta penghubung

g. Setiap sakelar harus disertai suatu petunjuk untuk posisi terbuka dan tertutup

4. Pemasangan Instalasi Penyalur Petir pada Kapal

Pemasangan instalasi penyalur petir pada kapal harus memenuhi syaratsyarat konstruksi, antara lain : ${ }^{9}$

a. Konstruksi instalasi penyalur petir pada kapal-kapal kayu atau kapal-kapal yang terbuat sebagian dari kayu yang memakai tiang kayu harus terbuat dari simpai tembaga atau kabel dengan garis penampang paling kecil 0,15 inci $(97 \mathrm{~mm})$.

b. Tiang-tiang besi dipasang pada kapal-kapal kayu atau sebagian dari kayu harus dihubungkan dengan pelat tembaga seperti tersebut dalam angka $1 \mathrm{di}$

\footnotetext{
${ }^{9}$ Ibid, halaman 145
} 
atas, dengan perantaraan kabel tembaga yang dipasang dengan kuat pada tiang besi.

c. Kapal-kapal baja yang memakai tiang kayu harus diperlengkapi dengan instalasi penyalur petir yang terbuat dari simpai tembaga atau kabel akan memakai alat penerima seperti yang dimaksudkan pada angka 1 dan ujung penyalur ke bawah ini harus dihubungkan dengan bagian dinding kapal pada tempat yang terdekat.

d. Penyalur-penyalur harus dipasang sedapat mungkin secara lurus dan sudutsudut yang tajam harus dihindarkan, dan klem harus terbuat dari tembaga atau kuningan serta memakai jaminan (borg).

e. Tahanan (weerstand) instalasi penyalur yang diukur antara bagian atas dari tiang dan pelat tanah atau penyambung dengan dinding kapal tidak boleh lebih dari 0,02 Ohm.

f. Perlindungan pada dok kapal

Dianjurkan agar pemasangan instalasi penyalur petir dari kapal-kapal yang berada pada dok disambungkan dengan tanah.

5. Penyebab kebakaran di atas kapal daerah bahaya kebakaran ${ }^{10}$

a. Penyebab kebakaran di ruangan mesin, meliputi :

- Kebocoran cairan mudah terbakar kesalahan atau rusaknya connection (hubungan)

- Isolasi atau penyekatnya menyerap minyak

- Permukaan panas seperti pipa pembuangan, bagian mesin yang menjadi terlalu panas yang diperkirakan dekat dengan aliran minyak

- Permukaan panas, seperti pipa buang bagian mesin yang panasnya lebih yang berdekatan dengan alur minyak

- Pekerjaan panas seperti penjelasan pemotongan dengan nyala oxyacetylene

- Penyalaan otomatis seperti tetesan minyak pada permukaan yang panas

b. Penyebab kebakaran di dalam akomodasi, meliputi :

- Material yang mudah terbakar

${ }^{10}$ Politeknik Ilmu Pelayaran Semarang, Advanced Fire Fighting, halaman 5 
- Korek api dan penghisap rokok termasuk ceroboh membuang rokok yang masih menyala atau abu

- Tekstil yang berdekatan dengan bahan yang panas seperti radiator dan lampu

- Hubungan pendek dan sistem peralatan listrik yang over loaded

- Di dalam louadry, instalasi yang rusak dari tromol pengering atau kegagalan dalam menjaga kebersihan

c. Penyebab kebakaran di dapur, meliputi :

- Cairan dan lemak mudah terbakar yang mempunyai panas lebih

- Penggorengan yang panasnya berlebihan

- Permukaan yang panas

- Tidak sempurnanya hubungan peralatan listrik

d. Penyebab kebakaran di dalam ruangan radio atau ruangan battery dan listrik, meliputi :

- Kelebihan beban dan hubungan pendek

- Kelemahan isolasi

- Pebah dan lepasnya hubungan

- Dalam ruangan battery, timbulnya hydosen (disebabkan kurangnya ventilasi) dan timbulnya pembakaran seperti dari merokok

e. Penyebab kebakaran di palkah dan dalam container, meliputi :

- Muatan yang mudah memanas sendiri dan mudah terbakar (batu bara, kopra)

- Muatan curah yang mudah mengeluarkan gas mudah terbakar (batu bara)

- Rusaknya ikatan yang berisikan bahan peledak, mudah terbakar atau zat-zat yang bereaksi

- Kumpulan bahan-bahan yang mengandung minyak akibat dari kurangnya pembersihan dan kebocoran tangki-tangki

6. Cara Pemadam Kebakaran ${ }^{11}$

a. Cara penguraian

\footnotetext{
${ }^{11}$ Politeknik Ilmu Pelayaran Semarang,Basic Safety Training, halaman 4
} 
Cara memadamkan kebakaran dengan memisahkan atau menjauhkan bahan/benda-benda yang dapat terbakar.

b. Cara pendinginan

Cara memadamkan kebakaran dengan menurunkan panas/suhu.

c. Cara isolasi/lokalisasi

Cara pemadaman kebakaran dengan mengurangi kadar/prosentase oksigen, pada lokasi di sekitar benda-benda yang terbakar.

7. Penanganan Bahaya Kebakaran di Kapal

Penanggulangan bahaya kebakaran meliputi : ${ }^{12}$

a. Guna menanggulangi kebakaran di kapal, maka kesiapan berupa tersedianya dengan cukup dan baik berbagai sarana dan kelengkapan peralatan kebakaran, pola operasional penanganan serta kecakapan peralatan kebakaran, pola operasional penanganan serta kecakapan maupun keterampilan awak kapal yang melayani keterampilan.

b. Penyediaan sarana-sarana dan berbagai kelengkapan peralatan-peralatan kebakaran yang berkonstruksikan secara tetap maupun yang dapat dipindahkan ataupun dijinjing yang tersedia dengan baik dan dalam keadaan siap pakai.

c. Guna penanganan kebakaran, maka perlu dibuat sijil-sijil kebakaran yang merupakan suatu daftar dengan nama semua awak kapal yang terdaftar dalam sijil dengan tugasnya masing-masing apabila suatu penanganan kebakaran terjadi, seperti untuk kapal penumpang ada team darurat kebakaran.

8. Peraturan Kecelakaan Kapal

Hal-hal yang penting dan perlu dipahami mengenai pembatasan atau pengertian yang terdapat dalam Peraturan Kecelakaan Kapal Tahun 1940, antara lain $:^{13}$

1. Kapal yang memberi tunjangan, sebagaimana diwajibkan menurut Pasal 2 adalah :

a. Kapal yang mempunyai kedudukan sebagai kapal laut Indonesia

\footnotetext{
${ }^{12}$ Djoko Triyanto,Op.cit. halaman 151

${ }^{13}$ Ibid, halaman 155
} 
b. Kapal milik dari atau disewa tanpa awak kapal oleh perusahaan yang menjalankan usahanya seluruhnya atau sebagian terbesar di Indonesia atau menggunakan kapal tersebut seluruhnya atau sebagian terbesar di Indonesia

2. Mereka yang disebut sebagai awak kapal atau dipersamakan :

a. Tiap anggota awak kapal baik sebagai nahkoda atau anak buah kapal yang bekerja pada sebuah perusahaan pelayaran di atau untuk kepentingan kapal yang diwajibkan memberi tunjangan

b. Orang lain yang bekerja dengan mendapatkan upah di atas atau di kapal yang wajib memberi tunjangan pada waktu kapal berada di pelabuhan/Bandar, dok-dok, stasiun karantina dan sebagainya di wilayah Republik Indonesia

c. Mereka yang tidak menerima upah, para magang, murid, penumpang yang melakukan pekerjaan pelaut dan orang semacam itu yang bekerja di atau untuk kepentingan kapal yang wajib memberikan tunjangan

d. Mereka yang berdasarkan perjanjian pemborongan pekerjaan melakukan pekerjaan di atau untuk kepentingan kapal yang wajib memberikan tunjangan, yang sudah dilakukan secara rutin (biasa)

e. Mereka yang bekerja pada seorang dengan siapa perusahaan pelayaran mengadakan perjanjian pemborongan pekerjaan di atau untuk kepentingan kapal yang diwajibkan memberikan tunjangan yang biasa di kapal itu.

3. Yang berwenang untuk mengurus terjadinya kecelakaan menurut S.O.R adalah :

a. Di Indonesia :

1. Syahbandar-syahbandar masing-masing bagi tempat kedudukannya

2. Pejabat-pejabat administrator pelabuhan yang ditunjuk oleh Kepala Direktorat Jenderal Perhubungan Laut

3. Pegawai lain yang ditunjuk oleh Direktorat Jenderal Perhubungan Laut

b. Di Luar Negeri : 
Dilakukan oleh pegawai Perwakilan Republik Indonesia bila ada pegawai yang demikian di tempat terjadinya kecelakaan.

Kecelakaan kapal adalah kecelakaan yang menimpa kapal dan segala isinya. Sedangkan arti kecelakaan itu sendiri adalah kejadian yang sekonyong-konyong atau tiba-tiba atau mendadak yang menimpa seseorang dan mengakibatkan hilangnya penghasilan baik sebagian atau seluruhnya untuk sementara waktu atau seterusnya dengan demikian, kecelakaan kapal akan membawa dampak yang tidak menguntungkan bagi pelaut apalagi bagi penumpangnya. ${ }^{14}$ Menurut Pasal 2 ayat (2) Peraturan Pemerintah Nomor 1 Tahun 1998 tentang Pemeriksaan Kecelakaan Kapal disebutkan ada 5 (lima) macam kecelakaan kapal yang meliputi :

1. Kapal tenggelam

2. Kapal terbakar

3. Kapal tubrukan

4. Kecelakaan kapal yang menyebabkan teracamnya jiwa manusia dan kerugian harta benda

5. Kapal kandas

Penyebab kecelakaan ada bermacam-macam, di samping karena kelalaian manusia (pelaut) termasuk tua usia kapal yang digunakan berlayar, juga ada yang disebabkan karena bahaya-bahaya laut sebagaimana ditulis Baharudin Lopa (1984), antara lain :

1. Angin topan

Jika pelaut-pelaut telah mengetahui akan datangnya angin topan yang berhembus, mereka sebaiknya mengambil langkah-langkah :

- Menutup semua permukaan perahu, yang dapat dilalui air masuk ke dalam geladak kapal atau perahu.

- Memperbaiki semua tali-temali dan semua perlengkapan/peralatan yang tersedia.

- Mengikat dengan kuat (erat) semua benda-benda perlengkapan/peralatan yang mungkin dapat disapu ombak besar.

2. Hantu Laut

\footnotetext{
${ }^{14}$ Ibid, halaman 159
} 
Hantu laut pada umumnya muncul dalam bentuk titik-titik yang menyerupai kunang-kunang (kembang api) yang hinggap di atas tiang layar, yang kemudian dalam waktu beberapa saat saja berubah menjadi air, dan makin lama makin membesar memenuhi seluruh ruangan kapal yang dapat menenggelamkan.

3. Gurita besar

Gurita besar adalah sejenis binatang laut yang mempunyai jari-jari tiga buah. Besarnya jari-jari itu sebesar pohon kelapa dan memiliki panjang antara 10-20 meter. Binatang tersebut pada umumnya menyerang pada waktu malam hari.

4. Laso Angin

Laso angin biasanya berupa sebatang tetesan hujan raksasa yang tampak turun dari segumpal awan.

5. Kala-Kala

Kala-kala adalah timbul karena pertemuan antar dua aliran arus yang bertentangan yang muncul ke permukaan laut sebagai kolakan atau tirisan atau pusaran air yang berupa ombak yang berputar-putar dan bergelora (tinggi) yang menyebabkan kapal ikut berputar-putar bahkan menenggelamkan kapal.

6. Batu karang

Batu karang yang besar-besar sering kali mengkandaskan kapal bahkan dapat menghancurkan kapal.

Selain bahaya-bahaya laut seperti yang telah disebut di atas sering pula terjadi adanya dua atau lebih perahu yang bertubrukan di laut. Bila ada dua perahu berselisih di jalan,maka supaya jangan terjadi suatu tubrukan, maka perahu yang berada di atas angin harus memberi jalan perahu-perahu yang lain itu, dengan menempatkan perahu itu di atas angin, sebab perahu-perahu ini susah sekali melawan gelombang dan angin. Bila suatu kejelekkan terjadi , maka perahu yang berada di pihak yang salah harus menanggung semua kerugian (M Sanusi Dg. Matatta, 1953 : 384). Untuk menghindari terjadinya tubrukan perahu di laut, apabila dua perahu atau lebih akan bertubrukan maka untuk menghindari tubrukan perahu yang sedang dikenai angin harus memberi 
kesempatan kepada perahu yang dilindungi oleh angin untuk dapat lewat lebih dahulu. $^{15}$

Ketentuan-ketentuan yang mengatur atau membahas ganti rugi jika terjadi kecelakaan kapal terdapat dalam Pasal 10 sampai Pasal 14 Schepelingen Ongevallen Regeling 1940, antara lain :

1. Pengobatan dokter dan perawatan awak kapal yang mendapat kecelakaan dengan cuma-cuma termasuk pemberian obat dan alat pembalut yang diperlukan, selama paling lama satu tahun sejak hari kecelakaan.

2. Pemondokan dan makan dengan cuma-cuma bagi awak kapal yang mendapat kecelakaan bila ia dirawat di kapal atau suatu tempat lain daripada rumahnya,

3. Pengangkutan bagi awak kapal ke tempat perawatan dengan cuma-cuma

4. Penguburan dengan cuma-cuma bagi awak kapal yang kecelakaan dan meninggal dunia.

5. Biaya pengangkutan yaitu penghidupan dan penginapan selama perjalanan dari tempat ia dirawat sampai kembali ke tempat perjanjian kerja berakhir :

a. Jika harus dirawat di tempat yang bukan merupakan tempat akhir perjalanan yang telah diperjanjikan.

b. Jika ia pada waktu kedatanganya di tempat akhir perjalanan yang telah diperjanjikan tidak lagi mampu melakukan pekerjaan yang dapat ia lakukan pada waktu kecelakaan.

6. Ganti rugi kehilangan perlengkapan karena kecelakaan kapal menurut ketentuan yang ditetapkan oleh Pemerintah.

7. Ganti rugi bila awak kapal cacat sama sekali untuk selama-lamanya, sehingga tidak mampu untuk melakukan pekerjaan besarnya 50\% sejak saat awak kapal upahnya dihentikan sebagian.

8. Ganti rugi cacat sebagian bila awak kapal mengalaminya ditentukan persentasenya dalam lampiran S.O.R. 1940, dan bila tidak terdapat di dalamnya akan ditentukan oleh pegawai pengawas.

9. Ganti rugi untuk cacat sementara besarnya $80 \%$ dari upah yang diterima sampai paling lama 26 minggu sejak terjadinya kecelakaan kapal.

${ }^{15}$ Baharudin Lopa, Hukum Laut, Pelayaran dan Perniagaan, (Bandung : alumni, 1982) halaman 194 
10. Ganti rugi kepada ahli waris jika awak kapal yang mengalami kecelakaan sampai meninggal dunia.

Menurut ketentuan Pasal 6 S.O,R. 1940 dibatasi siapa saja yang berhak mendapatkan ganti kerugian, terdiri dari :

1. Janda, yaitu wanita yang pada waktu kecelakaan menjadi isteri dari awak kapal tersebut, atau jika awak kapal tersebut mempunyai isteri lebih dari satu.

2. Duda yang tidak mampu bekerja, jika pada waktu kecelakaan kehidupanya seluruhnya atau sebagian terbesar menjadi tanggungan awak kapal wanita yang meninggal dunia.

3. Awak yang sah dan yang diakui sah, dibawah usia 16 tahun yang penghidupan seluruhnya menjadi tanggungan awak kapal yang meninggal dunia.

Pembayaran ganti rugi atau santunan tersebut dapat batal atau gugur jika terjadi :

a. Kecelakaan yang terjadi disebabkan faktor kesengajaan dari awak kapal.

b. Kecelakaan tersebut semata-mata karena kesalahan besar dari yang tertimpa kecelakaan.

c. Kecelakaan terjadi dan awak kapal sedang mabuk atau meminum minuman keras.

\section{Simpulan}

Pelaksanaan perlindungan hukum terhadap tenaga kerja di kapal atau anak buah kapal berdasarkan bentuk perlindungannya, dapat dilihat dari segi perjanjian kerja laut, jika dilihat dari perlindungan hukum tenaga kerja di laut kaitannya dengan resiko bahaya di laut maka tidak mencerminkan kepastian hukum yang pasti. Karena, dalam perjanjian kerja laut hanya menyebutkan secara umum tidak secara detail.

\section{Daftar Pustaka}

Ashofa, Burhan, Metode Penelitian Hukum, Jakarta: PT Adi Mahasatya, 2001.

Asyhadie, Zaeni, HUKUM KERJA Hukum Ketenagakerjaan Bidang Hubungan Kerja, Jakarta :PT Raja Grafindo Persada,2007. , Aspek-Aspek Hukum Jaminan Sosial Tenaga Kerja Indonesia,

Jakarta: PT Raja Grafindo Persada, 2008.

Sucipto, Cecep Dani, Keselamatan dan Kesehatan Kerja, Gosyen Publishing, 2014.

Soemitro, Ronny Hanitijito, Metodologi Penelitian Hukum dan Jurimetri, Jakarta: Ghalia Indonesia, 1995. 
Husni, Lalu, Hukum Ketenagakerjaan Indonesia, Jakarta: Raja Grafindo Persada, 2000.

,Perlindungan Buruh dalam Dasar-dasar Hukum Perburuhan, Jakarta: PT.Raja Grafindo Persada, 2004.

Idrus, Muhammad, Metode Penelitian Ilmu-Ilmu Sosial, (pendekatan kualitatif dan kuantitatif), Yogyakarta: UII Press, 2007.

Khakim, Abdul, Pengantar Hukum Ketenagakerjaan Indonesia, Bandung: PT Citra Aditya Bakti, 2003.

Lopa, DR Baharudin, Hukum Laut, Pelayaran dan Perniagaan, Bandung: Alumni, 1982.

Muhammad, Abdulkadir, Hukum dan Penelitian Hukum, Bandung: Citra Aditya Bakti, 2004.

Nazir, Moh, Metode Penelitian, Jakarta: Ghalia Indonesia, 2003.Politeknik Ilmu Pelayaran, Basic Safety Trainning.

Politeknik Ilmu Pelayaran, Advanced Fire Fighting.Ramli, Soehatman, Seri manajemen K3, Sistem Manajemen Keselamatan

Rusli, Hardijan, Hukum Ketenagakerjaan, Bogor: Ghalia Indonesia, 2011.

Soedjono, Wiwoho, Hukum Laut, Khusus Tentang Pengangkutan Barang di Indonesia, Yogyakarta: 1986. ,Hukum Perjanjian Kerja Laut, Jakarta: 1987.

Soekanto, Soerjono, Pengantar Penelitian Hukum, Jakarta: UI Press, 1986.

Soepomo, Iman, Pengantar Hukum Perburuhan, Jakarta: Djambatan, 1981. Suma;mur, Perlindungan Hukum Pekerja/Buruh atas Keselamatan Kerja dan Kesehatan Kerja, Jakarta: 2013.

Surataman dan Philips, Metode Penelitian Hukum, Bandung: Alfabeta, 2014.

Sutedi, Adrian, Hukum Perburuhan, Jakarta: Sinar Grafika, 2009.

Triyanto, Djoko, Bekerja Di Kapal, Bandung: Mandar Maju, 2005. , Hubungan Kerja Pada Perusahaan Jasa Konstruksi, Bandung: 2004.

Woerjati, Sri, Hukum Ketenagakerjaan Keselamatan Kerja dan Perlindungan Upaya Pekerja Wanita, Bandung: 1998. 